\title{
2 Bright red shiny pots: is there more to terra sigillata?
}

How did the homogeneous archaeological pattern of terra sigillata emerge? One important facet of this question concerns how sigillata was and is constructed as a homogeneous category in practices of study. To explore this, I will first present the generally accepted definition of sigillata in (Roman) archaeological and specialist circles. We will then see what happens to sigillata when we change perspective from retrospection to a description of the everyday practices involved in its study. The last part of this chapter extends this change of perspective to a longer history of sigillata scholarship. But before embarking on this project, you can choose to read 'a survival guide to terra sigillata', telling you everything you need to know to make it to the end of this book without prior knowledge of Roman pottery.

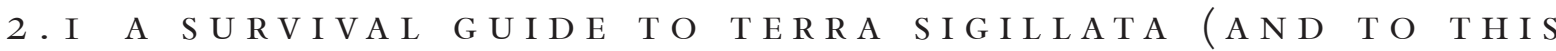 B O O K )}

What do you need to know about terra sigillata pottery to make it through this book without a nervous breakdown? Slightly at odds with the way the rest of the narrative is set out, this section will give you a specialist's account of terra sigillata, not unlike how a scientist would explain what quarks are on a radio show for the general public.

Suppose you are excavating in the Mediterranean area and the stratigraphy reaches Roman-period levels. The shiny red potsherds in those levels will without a doubt be terra sigillata pottery (Fig. 1.1). They will stand out visually both from the soil matrix and from the rest of the pottery and finds. They will be easy to wash and will often have relatively sharper breaks than other pottery from the same context. Both students and pottery specialists will be generally more excited upon finding them than when retrieving other pottery: the former because of the visual appeal of the sherds; the latter because they will know these sherds will enable them to date the layer to within a decade.

Terra sigillata pots are often called 'table wares'. This refers to the way they were used in the past: on Roman-period 'tables' (by way of speaking), for eating, drinking, and serving food. Their shapes fit these functions: cups, bowls, plates, and dishes. The actual correlation between these contemporary functional labels (e.g. what we think of as a 'cup') and the past use of specific terra sigillata forms is not always clear. ${ }^{63}$ Experimental studies have shown that some 'cup' shapes were used for mixing rather than for drinking. ${ }^{64}$ Moreover, just like we can use a mug today for drinking coffee but also for holding pens on one's desk, a single form could have been used for different purposes in the past. But generally speaking, sigillata forms strongly lent themselves to drinking, eating, serving, and 'light' food preparation such as mixing. Sigillata shapes also come with a footring, which allows them to stand up straight on a table or surface, but makes it difficult to use the pots on a fire or other device for cooking (cooking vessels generally have flat bases).

In addition, sigillata pots were slipped: after being formed on the wheel, they were dipped in a very fine clay emulsion that attained glaze-like qualities during firing (a process called 'sintering'). The sintered slip covered inside and outside of the vessels, and made them impermeable. In all likelihood this quality appealed to users, and made sigillata pots especially suitable for containing (semi-)liquids. At the same

63 Cool 2006; Dannell 2006.

64 Biddulph 2008. 
time, it affected these pots' thermal reactions, and discouraged use of these pots in combination with heat (e.g. cooking). Technical performance characteristics therefore combine with the form repertoire to shape possible uses.

Given these uses, one would expect to find these pots in domestic contexts and rubbish dumps, as is indeed the case. But 'eating' and 'drinking' as activities were associated with many contexts in the Roman period, and, as a result, sigillata pottery is a regular find in funerary and ritual assemblages as well. The fact that sigillata pots were deemed suitable containers or representations for eating and drinking in such 'out of the ordinary' situations is probably not unrelated to its special, shiny red surface (because of the sintered slip).

Sigillata's 'shinyness' has been read more specifically as alluding to more expensive metal vessels, the table ware of the well-to-do. A play with references to metal vessels was not unique to terra sigillata, however, and ranges it in a long Mediterranean tradition of ceramic table wares with features that were hard to produce in ceramics but were a natural consequence of the techniques of producing metal vessels: polished, burnished, or slipped surfaces; angular shapes; and sometimes even fake hobnails referring to metal counterparts - a phenomenon known as 'skeuomorphism' or imitation across media. For ancient Greek black- and red-figured vases, Vickers and Gill famously argued that not only their shapes but also their colour acted as a referent for metal vessels, with black standing for silver and red for gold. ${ }^{64 a}$

Before the development of terra sigillata at the very end of the Republic and its take-off in the early imperial period, the archetypical table wares of the Roman Mediterranean had a black appearance (socalled black-gloss wares) ${ }^{65}$ It is not all that far-fetched then, to suggest a similar scheme of mimicry, whereby the black of black-gloss wares and the red of terra sigillata corresponded to (silver and gold?) metal vessels. A discursive relation towards metalware is also suggested by sigillata's decorative schemes. Terra sigillata pottery was decorated almost solely through moulding (Fig. 1.1). Ceramic moulds were impressed with combinations of individual (ceramic or wooden) dies (poinçons), representing figures, plants, or decorative elements (e.g. ovolo or bead-row; medaillons). The body of each decorated sigillata pot was then impressed in that mould while the clay was still wet; it would gradually shrink when drying which allowed the vessel to be removed from the mould; and could be finished off on the potter's wheel with the addition of foot and rim. As a continuation of the theme of mimicry and emulation, the moulded surfaces of terra sigillata pottery can be said to replicate the embossed metal vessels of the time (think of the British Museum's 1st century AD Warren Cup for an elaborate example of relief decoration in silverware). While the link with metal table ware was strong in the shapes, decoration, and finishing of early terra sigillata pottery ${ }^{66}$, soon terra sigillata production became its own referent. The material links between both media loosened - whatever their initial meaning - and sigillata pots became less angular and the figures of their moulded decoration less akin to metal embossings.

As an aside, the technique of moulded decoration is what led 19th century scholars to the name of terra sigillata, a faux Latin term translating as 'stamped earth(enware)' ${ }^{67}$ The name was coined by scholars working on finds in Germany, France, and Britain, which, we now know, were produced in Italy and Gaul. Gaulish products had previously been called 'samian' based on a wrongheaded attribution in Pliny, wheareas Italian vessels were named 'arretine' after the first well-known production site of Arezzo. Today the label 'terra sigillata' refers to both of these groups and has more international currency than the labels 'samian' and 'arretine' still sometimes used by UK-based scholars.

64a Vickers/Gill 1994.

65 See section 3.1.

66 Oswald/Pryce 1920, 6; Roth-Rubi 1997 traces the decoration of Italian terra sigillata and Eastern sigillata back to shared examples in silverware.

67 See section 2.3.1 for a history of sigillata scholarship and its terminology. 
By now it should be clear that what this book calls 'terra sigillata' is part of a longer and wider phenomenon of 'red slip wares'. During the Hellenistic period, the table ware koinè of the Mediterranean - which had included Greek painted pottery, Republican black-gloss wares, etc. - gradually turned from a black to a red surface colour. The reasons for this change remain unclear - fashion? symbolism? technology? - and need not be dwelled upon here. It is worth pointing out though that the change was subtler than previously imagined, with for instance some early terra sigillata forms executed in both a black and a red variant. ${ }^{68}$ Surface-filling relief decoration had already been used on black-gloss wares ${ }^{69}$, but the decorative technique and program of terra sigillata is traditionally traced back to Megarian bowls. Strictly speaking 'red wares' and not 'red gloss wares' as they were not slipped, Megarian bowls were produced in Asia Minor from the 3rd century BC with elaborate relief scenes. Their shape is strikingly similar to the main cup shape of later Italian sigillata, the Drag. 11, but never has a footring, so that Megarian bowls had to be handheld at all times.

The phenomenon of red slip wares kicked off properly with the 'Eastern sigillata' series. ${ }^{70}$ Eastern Sigillata A, produced in Turkey from around 150 BC onwards, had the widest distribution, reaching as far as Italy and sites throughout the Western Mediterranean..$^{71}$ This was a time of intense political and cultural interaction between Italy and the Eastern Mediterranean, and no doubt the knowledge of pottery traditions rode back and forth on waves of conquest and fashion. ${ }^{72}$ It is therefore no surprise that historical hypotheses on the origin of Italian terra sigillata production drew on links with the Eastern Mediterranean: Oxé suggested that slaves of M. Perennius Tigranus were given to Augustus after the fall of Alexandria ${ }^{73}$, and Pedroni stresses the economic connections established by Pompey's campaigns in the Eastern Mediterranean. ${ }^{74}$ Despite being undeniably part of a Mediterranean-wide koinè of pottery traditions and fashions though, early Italian terra sigillata production was firmly anchored in the local knowledge of black-gloss ware production. Continuity in production sites and in some forms was (sometimes) paired with a new colour and/or new forms. Any fixed starting date of 'proper' Italian sigillata production will therefore be arbitrary, but 40-30 BC is often used as analytical threshold, albeit a conservative one that will no doubt need to be moved back in time. Italian sigillata production seems to have been primarily an urban phenomenon, with concentrations of workshops in Arezzo, Pisa, Pozzuoli, Cales, and probably, Rome, but the more research advances, the more the importance of rural production is brought to light. ${ }^{75}$ In addition, the genitive construction of potters' stamps suggests slave labour played a large role in production. ${ }^{76}$

As Italy and Rome culturally re-invented themselves as the centre of the Mediterranean in the Augustan period, Italian terra sigillata production in turn influenced its Eastern counterparts. For Eastern Sigillata D the possibility of 'subsidiary factories' of Italian workshops has been raised ${ }^{77}$, and by $20-15$ BC Italian owners possibly set up 'branch workshops' in Lyon in Central Gaul with a view to tapping the northern military markets via the river Rhône ${ }^{78}$. The reach of Italian terra sigillata, which started to be traded northwards, across the Alps, as well as throughout the Mediterranean, was such that it impacted on

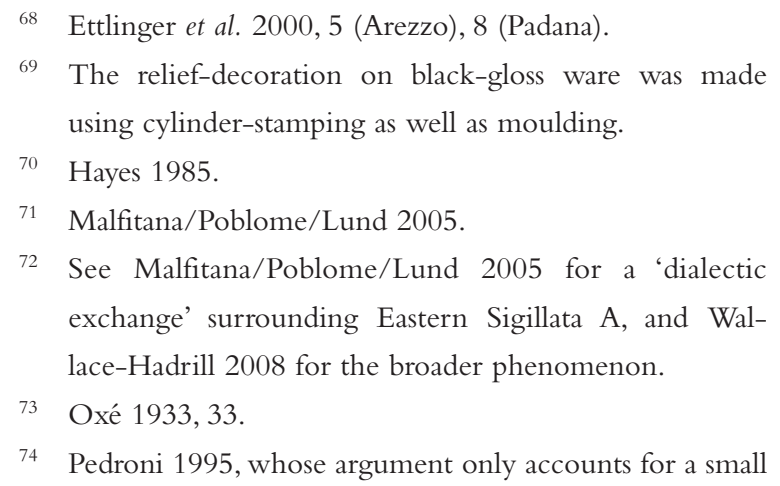

number of producers attested by the early potters' stamps.

75 Van Oyen 2015d for discussion. Bergamini 2004; Cuomo di Caprio 2007; Ettlinger et al. 2000; Kenrick 1993, 1997; Menchelli 2005; Olcese 2004; Poblome et al. 2004; Pucci 1985, 1990; Vaccaro et al. forthcoming.

76 Fülle 1997; Pucci 1973.

77 Zabechlicky-Scheffenegger 1995.

78 Desbat 2001; Desbat/Genin/Lasfargues 1996; Picon/ Lasfargues 1974; Picon/Garmier 1974. 
pottery traditions outside of the Mediterranean table ware koinè, which adopted sigillata's red colour and basic shape-types (e.g. plates in 'Gallo-Belgic' ware, produced in the northwest provinces from around $15 \mathrm{BC}) .^{79}$

This book deals with the small subsection of the red gloss phenomenon that is of most historical relevance to the western Roman provinces: the Gaulish terra sigillata production. The possible Italian branch workshops in Lyon were shortlived, but momentum built in other Gaulish production sites where indigenous knowledge in ceramic production had met the technical innovations of terra sigillata production at the end of the 1st century BC. The site of La Graufesenque in South Gaul became the main supplier of red slipped wares to Gaul, Britain, the Rhineland, and northern Spain in the 1st century AD, only to be replaced a century later by Central Gaulish products, predominantly from the workshops at Lezoux.

Spain also witnessed the installation of local terra sigillata production in the first half of the 1st century AD, with Andújar and Tritium Magallum as major sites, but on the whole export was less wide reaching than was the case for Gaulish terra sigillata. ${ }^{80}$ Neither the main Spanish production sites nor more local initiatives lasted much beyond the 2nd century AD. African red slip wares (ARS), produced in Northern Africa (especially the area of present-day Tunisia) from the 1st century AD onwards, fared better. ${ }^{81}$ ARS, with its distinctive thick, orange-red slip, had become the main table ware of the entire Mediterranean by the 3rd century AD at the latest, and continued to thrive well into Late Antiquity, up to the 7 th century AD.

In Gaul, terra sigillata production fragmented into a series of smaller, more regionally grouped workshops with generally more modest output and distribution, in the Moselle in the 1st and 2nd centuries AD (e.g. Boucheporn; La Madeleine) ${ }^{82}$, and in East Gaul in the 2nd and 3rd centuries AD (e.g. Blickweiler; Rheinzabern; Trier) ${ }^{83}$. By the late 3rd century, the terra sigillata technology properly speaking was considerably redefined in the western provinces, but its material memory lasted into the 5th century through the forms and appearance of local table ware traditions, such as Oxfordshire and Hadham redslipped wares in Britain ${ }^{84}$, and Argonne wares in Gaul ${ }^{85}$.

Finally, some notes on the technology of Gaulish sigillata are in place. Analysis of technological choices is key to the argument of this book, so further specifications will follow in due course. For now it suffices to point out the basics. The first crucial step in sigillata production consisted of selecting the right clays. Gaulish sigillata production distinguished itself from previous traditions of ceramic technology by selecting only specific kinds of clays, generally clays with a high calcareous content. ${ }^{86}$ It is as yet unclear whether these clays performed better or whether this choice was constrained by other parameters - this is a question explored in what follows. After its selection and mining, clay preparation further helped create the right plasticity. Terra sigillata clays were refined through levigation: the clay was sent through a series of overflowing basins, each of them retaining a part of the sunken, coarser matrix. Probably alternative or complementary preparation methods were in use as well, as levigation basins are not attested on all sites, but other infrastructure is (e.g. large paved areas).

Once the clay had attained the right composition, each vessel was formed individually on the fastturning wheel. Moulds were used to model the body and decoration of decorated vessels, but plain wares - the majority of terra sigillata produced - were hand thrown. Nevertheless, measurement shows an extreme consistency in the resulting shapes and size modules of plain sigillata vessels ${ }^{87}$, which suggests the use of templates and formers, probably in wood and rarely found in archaeological contexts. ${ }^{88}$ After

79 Ettlinger et al. 2000, 22-25.

s0 Mayet 1984.

1 Bonifay 2004; Hayes 1972, 1980.

2 Brulet/Vilvorder/Delage 2010, 134-152.

83 Brulet/Vilvorder/Delage 2010, 168-201. Chapter 5 discusses terra sigillata produced at Trier.
84 Tyers 1996.

85 Brulet/Vilvorder/Delage 2010, 216-253

86 Picon 1973, 2002a.

87 Monteil 2012.

88 P. Webster 2001, 289-290. 
forming, but when the clay was still wet, a stamp was impressed on the inner base of some vessels. In Gaulish production, these stamps record names, often combined with a formulaic abbreviation such as 'FEC[it]' ( $\mathrm{x}$ 'made this') or 'OF[ficina]' ('the workshop' of $\mathrm{x}$ ). In all likelihood the stamps fulfilled a role in the organisation of production, probably referring to workshop owners rather than the potters who actually formed the vessels, but their precise function remains unclear and probably changed considerably over time ${ }^{89} \mathrm{Next}$, pots were dipped upside-down (as occasional lighter patches and fingerprints near the base testify) in the slip, a fine clay emulsion that appears to have been prepared from separately mined clays. Subsequently pots were left to dry, and grit stuck to the footring of unused Gaulish terra sigillata pots suggests this was done on a sandy surface, to avoid vessels getting stuck..$^{90}$ The loss of water during drying meant a considerable shrinkage, which allowed decorated vessels to be removed from their moulds.

The production sequence then arrived at its moment of truth: firing. Along with the clay selection, firing is what made terra sigillata stand out in technological terms. In order to guarantee a bright red, shiny appearance, sigillata pots had to be fired in an oxidizing atmosphere, in which the pots did not enter into contact with fumes or gases containing $\mathrm{CO}_{2}$. Normally, pottery kilns created a reducing atmosphere during the actual firing stage, in which fumes touched on the ceramics and speeded up the process. Kilns would then be opened or exposed to oxygen upon cooling, which, depending on the clays used, would allow pots to turn red. But this 'normal' redness was not guaranteed, nor was it as vibrant as terra sigillata red.Terra sigillata pots, instead, were never exposed to fumes, not even during the first stage of firing. Therefore special kilns had to be constructed, and in Gaul the solution was to build ceramic tubes (tubuli (Latin) or tubulures (French)) that led the hot gasses from the heat source through the firing chamber, heating the pots without touching them. These special measures meant that the loading and unloading of kilns - which effectively entailed rebuilding the inner core of the firing chamber - were delicate and time-consuming exercises. Various types of kiln spacers and ceramic supports were used to keep the piles of plates, cups, and other shapes straight and separate and to avoid fusing between individual vessels stacked, usually base-upwards, on top of one another.

Chemical processes occurred more slowly in an oxidizing firing athmosphere. Yet the slip had to become 'sintered', meaning some of its molecules fused so as to produce a glaze-like shiny and impermeable effect. As a result, firing needed to maintain higher and more consistent temperatures for longer periods of time than was the case in a reducing athmosphere. Terra sigillata kilns had to reach temperatures between $1050^{\circ} \mathrm{C}$ and $1100^{\circ} \mathrm{C}-$ much higher and more consistent than 'normal' kilns which generally attained around $800^{\circ} \mathrm{C}$ with irregular peaks up to $1000^{\circ} \mathrm{C} .{ }^{91}$ The sigillata firing process needed to be carefully managed and relied not only on expert skills but also on high fuel input, mostly wood, although alternative sources cannot be ruled out. ${ }^{92}$

Kilns of Gaulish sigillata production were not only of special construction; they could also be exceptionally large indeed. The grand four at La Graufesenque measured no less than $7 \times 7 \mathrm{~m}$ in surface, with pots stacked several metres high. Production volumes were concomitantly massive, with estimates for the number of pots leaving La Graufesenque at the peak of its success amounting to 15 million per year. ${ }^{93}$ The actual organisation of the workshops is food for debate. ${ }^{94}$ Obvious differences with Italian sigillata production are the rural locations of Gaulish workshops, and the apparent lack of potters of servile status (although slaves could still perform subsidiary tasks such as marketing).

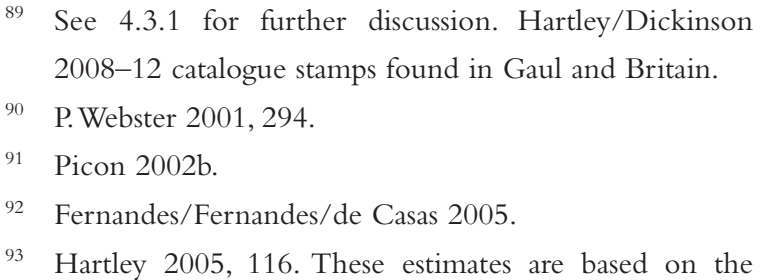

firing lists, discussed in Chapter 4, which suggest that single kiln loads could contain up to 30,000 vessels.

94 Dannell 2002; Fülle 2000a, 2000b; Strobel 1992; P. Webster 2001. See 4.3.1 for more extensive discussion of production organisation. 
Having digested this traditional survival guide, even readers without prior knowledge of Roman archaeology should be able to follow the non-retrospective argument about terra sigillata pottery that starts here.

\subsection{TERRA SIGILLATA AS IT IS KNOW N THROUGH CURRET PRACTICES OF ST U DY}

\subsection{A S T A D A R D DEFINITION OF TERRA SIGILLATA}

Terra sigillata is a modern name archaeologists give to a type of pot dating to the Roman period. A dictionary definition on which all archaeologists would agree runs as follows. Terra sigillata is a type of bright red glossy Roman tableware, used for dining and serving purposes. It was produced in a limited number of centres roughly between the 1st century BC and the 3rd century AD (barring 'Eastern sigillata') and distributed all over the Roman empire.

Narrowing down the readership to Roman archaeologists, a dictionary might hint at sigillata's possible associations with a Roman cultural identity, with Roman foodways, with the Roman army, etc. Moreover, all Roman archaeologists know how to identify pot(sherd)s they find as sigillata. This is because a core package of fixed traits proves sufficiently comprehensive in day-to-day fieldwork practice to allow correct identification of sigillata: sherds with a bright red colour, shiny slip, a limited and standardized form repertoire, plain or carrying repetitive moulded decorations, and possibly fitted with an epigraphic name stamp.

These traits happen to be the first ones emphasized in the history of study of sigillata. But gradually cracks began to emerge in the comprehensiveness and accurateness of the above definition. For example, not all sigillata vessels were consistently stamped - most of the forms of Flavian date (last third of the 1st century AD) created at La Graufesenque for instance were not. ${ }^{95}$ Similarly, few of the plain forms of the so-called Ateius deposits of Arezzo - generally considered as key assemblages for Italian sigillata - match up with what have been defined as the core Italian sigillata types in the latest typology. ${ }^{96}$ Conversely, many pots look like sigillata ('imitation', 'derivatives'), but are they actually sigillata, and should archaeologists study them as such? Clearer boundaries were needed to define and identify what sigillata really is, to correct the ambiguities and biases inherent in apparently superficial and subjective criteria such as form or colour.

In order to construct such boundaries, sigillata specialists turned to technology. Anchored in material properties and measurable through scientific instruments, technology promised to lay down unbiased parameters for the definition and identification of sigillata.

In one of the most influential applications of the measuring potential of archaeometry to the study of sigillata, Picon detected two shifts in the type of clay in use at Lezoux (a major sigillata production centre in Central Gaul) for the production of sigillata: from non-calcareous to calcareous clays between the 1st and 2nd centuries AD (shift to 'real' sigillata), and back to clays with a less calcareous signature in the 4th century AD ('degradation' of the 'real' sigillata). ${ }^{97} \mathrm{~A}$ similar exclusive use of calcareous clays was in turn confirmed for sigillata productions in the area of Rome ${ }^{98}$, and at Arezzo ${ }^{99}$, Lyon ${ }^{100}$, and La

95 Vernhet 1976.

96 Ettlinger et al. 1990; Kenrick 1997.

97 Picon 1973; Picon/Vertet 1970.

98 Olcese 2004.

99 Picon/Vertet 1970, 207-211. Information on the chemical compositions of Italian sigillata is scant (Picon 2006,
433-434; Ettlinger et al. 1990, 27-38). No such exclusive use of calcareous clays can be established for the Padana region (Lavizzari Pedrazzini 1972, 2004; Picon 2006, 433).

100 Picon/Vichy/Meille 1971. 
Graufesenque. This recurrent pattern confirmed the existence of a significant correlation between 'real' sigillata and calcareous fabrics. ${ }^{101}$

In the same seminal study Picon formalized the technical process of firing ceramics by differentiating between three types: mode A (reducing firing atmosphere and oxidizing cooling atmosphere), mode B (reducing firing and cooling atmosphere), and mode $\mathrm{C}$ (oxidizing firing and cooling atmosphere). A switch from mode A to mode C firing accompanied the shift to calcareous clays observed at Lezoux, and this association was extrapolated as another defining criterion of 'real' sigillata.

Grounding in technology thus assured that a new sigillata package could be proposed, the constituent traits of which implied each other in a causal, non-random manner, contrary to the superficial relations between form, colour, etc. previously relied on. For example, the use of calcareous clays logically entailed high firing temperatures: a sufficiently elevated temperature had to be reached so that the $\mathrm{CaO}$ would no longer react with water and cause the vessels to collapse as they swelled with humidity. And because chemical reactions tend to occur with a delay in oxidizing compared to reducing firing atmospheres ${ }^{102}$, higher fuel consumption was needed to assure longer firing. This in turn explains why sigillata was more expensive to make and buy than the average Roman pot.

The ephemeral and subjective criteria used before could now be objectively anchored in physical processes and retrieved via scientific analysis. For example, 'shininess' was actually shown to be the visual correlate of a chemical process of sintering of the slips. Sintering in turn stood in a non-random relation to the firing mode: sintering could happen in either a reducing or an oxidizing firing atmosphere, but the outcome would be respectively black or red shiny slips. As a consequence, colour ('red') was no longer a subjective criterion of identification, but had become part of a technological cascade of cause and effect.

These new non-random parameters could then be added up to create a comprehensive and essential package of traits that defined sigillata. In turn these parameters consolidated the more tentative and general definitions with which this chapter started out. The intuition that 'all sigillata pots look the same' could now be grounded in scientific properties, and the category of sigillata was scientifically proven to be homogenous and self-contained. Any potsherd could be shown to either fall squarely within this category, or entirely outside of it. In order to uphold this model, it has to be assumed that those cases where potsherds are not easily sorted within or outside of the sigillata category show the limitations of the tools of study, not a problem with the category itself. For instance, chemical analyses used to characterise clays only have a limited accuracy and can lead to ambivalent results. It is then maintained that the potsherds in and of themselves are not ambivalent (either they qualify as sigillata or they do not), the problem of ambivalence lies with our tools. Following this logic, refinement in tools of study is the only avenue for improving our knowledge about terra sigillata.

2. I. 2 REINSERTING PRACTICES IN DEFINITIONS

It is in the nature of dictionary definitions to be established retrospectively, describing phenomena that are already known and defined. Moreover, different lemmas need to be clearly separate and cross-referenced in a non-random way. The previous section has shown how sigillata has been made to fit this dictionary model with the aid of scientific techniques. The change of perspective advocated by this book is to take dictionary definitions for what they are: only one kind of answer. It then becomes possible to acknowledge what falls through the cracks of the retrospective dictionary definition of sigillata.

First, the detail and measurability afforded by scientific techniques does not always help clarify sigillata's dictionary definition. Sometimes, instead, it ends up making things fuzzier. For example, the scientific identification of the process of sintering seemed to put sigillata's intuitive trait of 'shininess' on a more

101 Picon/Vichy 1974, 54. 
solid basis. But sintering indexes a gradual process rather than an instant, binary chemical phase transition. ${ }^{103}$ As a result, an arbitrary judgement has to be made where to place the threshold of a potsherd's degree of sintering for it to qualify as sigillata. In practice, this is very similar to the arbitrary judgement of just how shiny a sigillata sherd has to be.

Secondly, testing for scientific criteria is not always feasible in the context of archaeological fieldwork. Finds analysis still relies in large part on the 'superficial' criteria such as form, decoration and stamps. But their relation to the scientific parameters continues to be problematic. For example, archaeometry has shown that the later East Gaulish production centres of the 2nd and 3rd centuries AD no longer used strictly calcareous clays, despite producing pots that both looked like and chronologically followed on from calcareous sigillata. Are all traits in the dictionary definition of equal weight?

Instead of clarifying which pots count as sigillata and which ones do not, zooming in on scientific parameters seems to entail an ever more expanding and heterogeneous category of terra sigillata. Once this category 'bleeding' is acknowledged, it becomes difficult to halt. For example, production, distribution and consumption of the sigillata discussed in this research are limited to the western Roman provinces. In the eastern provinces, however, archaeologists identify a type of ceramics called Eastern sigillata. Others sometimes talk of red slip wares. And bright red pots dated to for instance the 4th century AD and excavated around the Mediterranean might well turn out to be African Red Slip Ware. ${ }^{104}$ Just how far does the equation between 'bright red sintered potsherd' and 'sigillata' reach? Does this mean that there are different kinds of sigillata? If so, how do they fit together, if at all?

Paradoxically, scientific techniques were brought in to do a job diametrically opposed to the way in which they operate. They were expected to lay down once and for all the essential package of traits that unambiguously defined sigillata in the past and the logically correlated indices by which specialists could reveal that package in the present. Instead, what these techniques did was to introduce ever more variability, and multiple dimensions of difference. If a dictionary definition could be distilled from this, it came at the price of erasing a great deal of empirical complexity and richness.

How to avoid paying that price? The answer is by avoiding a reification of the retrospective approach. Whereas we started out by stating that sigillata is a modern label used by archaeologists, at the end of last section that label had seamlessly taken on the aura of a past reality. Instead of trying to unveil a sigillata that is already there (as dictionary definitions do), this book wants to follow sigillata in the process of being made, of becoming. This shifts focus from the question of 'what is terra sigillata' to 'how is it being studied, made, distributed, etc.'.

One way in which sigillata is being made is in its everyday practices of study. These practices tend to be regarded as mere epistemological bridges linking observations (e.g. 'red colour') to scientific facts (e.g. sintering, and hence 'sigillata'): the question of 'how' is entirely subservient to the question of 'what'. In this book, instead, the question of 'how' is fundamental to the question of 'what': to understand what something is and how it is defined, look at how it is being made, used, and circulated. So how is sigillata being studied today and how does this affect the way in which it is being defined?

We have seen how a dictionary approach creates a certain framework for studying sigillata. It posits sigillata as a category to which any single excavated sherd can either belong or not - and has either belonged throughout its life history or not. Consequently, it becomes a valid research design to study all sherds belonging to this category, leaving out those pots not conforming to the package of traits laid down in the dictionary. This is how specialisation is born. Within sigillata scholarship - as within Roman archaeology more generally ${ }^{105}$ - specialisation is a pervasive trend. During excavation, sigillata tends to get separated from other finds. Allowing for a sufficient post-excavation budget, this sigillata assemblage

102 Picon 2002b.

103 Picon 2006, 434-436, $2002 \mathrm{~b}$.

104 The literature is ample, e.g. Cau/Reynolds/Bonifay
2011; Hayes 1972, 1980

105 Willis/Hingley 2007. 
is then sent off to a specialist for more precise identification. Because of her implicitly acquired expertise, the specialist is able to access even more of a single sigillata sherd's defining package: its production site, its date, or even its mould-maker or potter. This is again done on the basis of criteria for in-/exclusion: 'snow storm' effect due to white particles in the fabric identifies a sherd as 'South Gaulish'; form Dragendorff 33 with double groove and rather straight walls means 'South Gaulish' and '1st century AD'. ${ }^{106}$ This then leads to the publication of all sigillata finds from a single site, context or feature as a separate entry or class. Focusing on all specimens inside this class becomes a meaningful exercise because their internal homogeneity and their difference from other types of pottery is constitutive of their definition. Other factors allowing, meaningful comparisons can then be made between the 25 sigillata specimens found at site $\mathrm{x}$ and the 37 found at site $\mathrm{y}$.

The drawers for Roman period sites in the sherd room of the Museum of Classical Archaeology at Cambridge (and of many other museums with it) separate out sigillata sherds from other ceramics from the same sites. Separate drawers contain plain, decorated, and stamped sigillata fragments respectively. This organisation in turn facilitates practicals on terra sigillata as a separate topic: the material is readily accessed. It becomes more difficult if teaching starts from assemblages: sherds from various drawers need to be looked up in the catalogue, retrieved, and, more problematically, put back in the right place.

But as the implicit visual standards maintained in identifying sigillata tend to be gradual rather than binary, different specialists will only rarely reach a $100 \%$ closure for the identification of a single specimen. In practice, arguments tend to be closed by reference to authority and experience. It is no exception to see practitioners bringing a box of unidentified potsherds to a conference for identification by more experienced colleagues. Furthermore, gauging from conferences and publications during the last decades, there seems to be little or no interaction between for example those specialists studying African Red Slip ware and those working on Gaulish production centres or British consumption sites. The dissection of terminological debates within the field of sigillata studies gives another glance at how variability is coped with (or not) in practice. Vigorous debates have been waged for instance over some products variously denoted as 'pre-sigillata', 'proto-sigillata', or 'imitation sigillata' ${ }^{107}$ Should these be studied by sigillata specialists? Finally, with regard to the production site of Lezoux for example, it is clear that during large parts of its history sigillata has been absent or very minor compared to the output of other ceramic products. Does this warrant Lezoux going down in the history books as a 'sigillata production centre'?

There is a mutual reinforcement between the dictionary definition of sigillata as a homogeneous and self-contained category and the practices by which it is studied. For example, a positive feedback loop connects the flattening out of controversies regarding which pots count as sigillata and which do not on the one hand and the affirmation of the authority of specialists on the other. The unspoken guideline 'in case of doubt, consult a specialist' maintains the 'in' and 'out' boundary circumscribing what makes up the sigillata category. Similarly, pervasive specialisation a priori negates the relevance of possible relations between sigillata and other finds classes. The practical burden of retrieving sherds from various drawers in a museum encourages lectures focusing on sigillata as a separate category. Specialists are not merely studying sigillata, but are creating sigillata and intervening in its conditions of existence. Moreover, the way they process sigillata in the present creates sigillata in the past as a homogeneous category, defined by a clear-cut package of traits.

This last point needs emphasis: the way in which sigillata is being studied actively shapes a research domain, the questions asked, and the ways in which data can be arranged. Consider for example the label 'arretine' sigillata still in use in the UK to refer to sigillata produced on the Italian peninsula. ${ }^{108}$ No one would debate that this is a misnomer: while scholars initially found traces of sigillata production in Arezzo, many other centres have now been discovered in Italy. Nevertheless, the label still implicitly drives the

106 See Webster 1996.

107 Van Oyen 2013.
108 Let alone the flagrant misnomer of 'samian ware' derived from Pliny and still used in the UK for Gaulish sigillata. 
idea of Italian sigillata as an urban, centralized activity, which in turn steers research designs (e.g. little or no research in the 'empty' countryside ${ }^{109}$ ), and models of past organisation (e.g. opposition to the multifocal and widespread production landscape of earlier so-called black gloss fine wares $\left.{ }^{110}\right)$.

Other, more detailed ethnographies of archaeological practice of this kind have been done before. Holtorf employed direct observation and interview in order to follow a single potsherd from its excavation to its storage in a museum. ${ }^{111}$ Key was to render explicit the multiple practices that are implicated in deciding what this potsherd actually is. Both the physical characteristics of the sherd (e.g. size) and routines and 'good practices' (e.g. labelling) enable certain possibilities for what the sherd could be. For example, whether the sherd is identified as ancient or not depends on a long chain of actions from visual identification and experience by the digger ('it does not look recent') to correct labelling (in order not to be discarded) and laboratory analysis (when 'ancient' is narrowed down to '3rd century BC').

There are two possible responses to this account. Either we try and maintain a stable essence of this potsherd which assures the link between the different stages in its life history. This is what so-called biographical approaches amount to ${ }^{112}$ : a single thing with unaltered essence experiences different perturbations and acquires different meanings in different contexts. Let us assume the potsherd in question is a terra sigillata sherd. Then it may well have been defined subsequently as 'Roman', '2nd century AD', and 'AD 140-160 from the workshop of Cinnamus at Lezoux', as it went through more fine-grained mazes of analysis, by increasingly specialized people, and taking into accounts more of its traits (e.g. 'it is red and shiny' to 'its decorative scheme is characteristic of the Cinnamus workshop'). But following the biographical approach, it would always already have belonged to the homogeneous category of sigillata.

The alternative, explored in this book, is not to assume that this sherd has an essence that ranges it in the sigillata category at any stage of its biography. What if we accept that the potsherd does not have an essence over and above how it is articulated in a certain practice, in a certain stage of analysis? What if it really just is generically 'not recent' during excavation by a first year student and only becomes 'AD 140-160 from the workshop of Cinnamus at Lezoux' through analysis by a specialist? If we refrain from projecting backwards the result of a complex set of practices - 'AD 140-160 from the workshop of Cinnamus at Lezoux', and, more broadly, sigillata as a homogeneous category - we can finally grant defining leverage to those practices. Doing away with an essence means doing away with a priori continuity, and leads us to think much harder about the links, connections, and mediations between sigillata in different settings. It means that we can no longer assume commensurability between the 25 sigillata pots found at site $\mathrm{x}$ and the 37 found at site $\mathrm{y}$; or between the bright red shiny pots retrieved by the Medici in Arezzo in the Renaissance, and the bright red shiny pots drawn by Dragendorff in the 19th century and since known as the sigillata typology. This commensurability will have to be re-described as the outcome of contingent historical processes.

\subsection{TERRA S I G I L L A T A A S I T W A S K N OW N I N THE H I T O R O F I T S S C H O L A R H I P}

The previous section explored how the dictionary definition of terra sigillata as we know it today is enabled and maintained through its practices of study. These practices have changed throughout the history of sigillata scholarship, as different settings, techniques and conventions emerged. The following section

109 Despite discoveries of production on rural sites with mixed crafts and processing activities (e.g. Vaccaro et al. forthcoming on the Roman Peasant Project; Pucci 1990). Van Oyen 2015d on sigillata's relation to city and countryside.

\footnotetext{
110 Itself initially constrained by a 'dictionary' definition (Morel 1981; Principal 1998, 2006).

111 Holtorf 2002.

112 Appadurai 1986; Kopytoff 1986.
} 
will present a historiographical review of sigillata studies. ${ }^{113}$ But it will not do so retrospectively; it will not tell a story of the progressive unveiling of sigillata as tools and techniques became more and more refined. Instead, it will zoom in on the practices and settings of study, and on how these set certain limits and parameters for how sigillata as an object of study was defined. ${ }^{114}$ The separation of different analytical stages through time is of course artificial. But for every moment discussed below, new actors appear on the stage and irreversible shifts occur in the definition of sigillata.

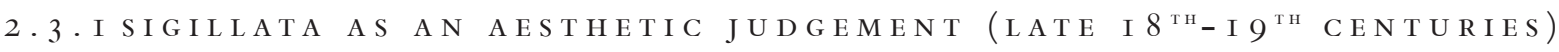

When did terra sigillata become an object of study? Ancient authors make references in passing, which have been invoked as historical sources throughout the history of scholarship on sigillata. Pliny the Elder (AD 23-79) wrote that " $[\mathrm{t}]$ he majority of mankind use earthenware vessels. Samian ware is recommended even at the present day for dinner services; this reputation is also kept up by Arretium in Italy (...) and exportation from the celebrated potteries goes on all over the world.' ${ }^{115}$ Isidore of Seville (ca. AD 560636) added 'Arretine vases are so called from Arretium, a town in Italy where they are made, for they are red. ${ }^{116}$ H.B. Walters, assistant in the Department of Greek and Roman Antiquities at the British Museum in the late 19th century, lists a series of more recent rediscoveries, from mentions as early as 1282 , to the unearthing of some 'red ware' in 15th century Arezzo in the presence of Giovanni de Medici. ${ }^{117}$ At this early stage, the most striking features seem to have been the red colour, the presence of stamps, and a specific function (dinner services). Moreover, both the references by ancient authors and the fact that the first discoveries of such specific red pots occurred at Arezzo spurred a discourse on origin, with specific focus on a number of renowned production sites.

Let us fast-forward to the second half of the 18th century and to the phenomenon of antiquarianism, anchored within the rise of European nation states. ${ }^{118}$ An important device of elite discourse was the Grand Tour, during which members of the European elites concluded their education by venturing into the classical lands and experiencing their material remains. ${ }^{119}$ As they returned to their home countries with portable and fascinating objects, the latter became loaded, featuring as tangible markers of participation in what was believed to be an authentic past, which in turn legitimated present and future aspirations.

The preferred objects of display had to fit a set of requirements: first of all, the need for portability limited the possible choice; secondly, culturally specific values made for a general preference for traces of (what was thought of as) creativity and skilled virtuosity. Consequently, as to pottery, a predilection can be noted for hand-painted vases (now classified as 'classical Greek', but at the time thought to have been 'Italian'120), resulting in a relative lack of attention for 'simple' red pots like sigillata. The repetitiveness of sigillata pots thwarted interest in all but the most elaborate specimens. Nevertheless, the visual immediacy of the shiny red slip, combined with some examples of decoration in line with a recently formalized classical canon ${ }^{121}$, made sigillata into a moderately sought after by-product of the Grand Tour, a second-rate alternative to Greek vases.

Generalization of the term terra sigillata had to wait until the second half of the 19th century. As an example of 'faux Latin', terra sigillata meant 'sealed earth', referring to the stamped decoration. This rein-

113 A rare good in Roman finds studies: Willis/Hingley 2007,7 .

114 See Pickering 1984.

115 Historia Naturalis XXXV $160 \mathrm{ff}$.

116 Etymologiae XX 4, 3.

117 Walters 1908, xv; Déchelette 1904, 10; Fabroni 1841;
Menchelli 2005.

118 Sweet 2004.

119 Bignamini/Hornsby 2010; Hornsby 2000; Wilton/ Bignamini 1996.

120 Jenkins/Sloan 1996; Sparkes 1996.

121 As defined by J.J. Winckelmann 2006 [1764]. 
forces the observation that decorated pots were held as exemplary. It is unclear just where and when the name originated. In the UK, C.R. Smith commented in 1849 on the inappropriateness of the label 'Samian', since Pliny made no explicit mention of Samos as a production centre. ${ }^{122}$ Smith was the first to hypothesize a Gaulish origin of these Samian vessels, in contrast to those fragments with more 'Greek style' decoration that were traceable to Arezzo. He did, however, make no mention of terra sigillata. The latter term featured prominently in the German title of Dragendorff's seminal paper almost half a century later (1895), and was taken up in the UK by Oswald and Pryce (1920). ${ }^{123}$

The limited space allocated to sigillata in handbooks of the 19th century illustrates the subject's secondary place in antiquarian practices. Marquardt's Römische Privataltherthümer (1864) considered aspects of 'Produktion, Fabrikation, und Handel' in relation to Roman family life. References in Greek and Latin vocabulary formed the only basis for his classification of ceramic vessels by function. ${ }^{124}$ While this speaks to a continued importance of function in how sigillata was defined at the time, it also indexes the prevalence of the written word in the 18th and 19th centuries. ${ }^{125}$ The high esteem for the written word can be traced back to Christian philosophy, and has greatly influenced the legacy of Classics in which the ancient authors occupy an authoritative position. In this regard, another asset of sigillata was the presence of writing in the form of epigraphic name stamps. Shiny red colour and decoration come to the fore too in Marquardt's work, who characterised sigillata as those ceramics which 'zeichnen sich aus durch corallenrothe Farbe, haben meistens Glasur und sind mit zierlichen Reliefs versehen'. ${ }^{126}$ Lastly, Marquardt relocated the polarization between the craftsmanship of Greek painted pottery and the repetitiveness of mass-produced Roman pottery within Roman ceramic categories themselves. He distinguished between fine wares (such as sigillata) made by individual potters and workshops, and coarse wares and building materials taken over by 'capitalist' production. ${ }^{127}$ For Marquardt, sigillata stood as a creative counterpoint to contemporary capitalism and industrialization.

While Samuel Birch's History of Ancient Pottery (1873) reserved the entire first volume and half of the second to painted (Greek) vases, Roman ceramics had to make do with some 250 pages. ${ }^{128}$ Even more explicitly, Birch wrote that

'Roman vases are far inferior in nearly all respects to Greek; the shapes are less artistic, and the decoration, though not without merits of its own, bears the same relation to that of Greek vases that all Roman art does to Greek art. (...) Roman vases, in a word, require only the skill of the potter for their completion, and the processes employed are largely mechanical, whereas Greek vases called in the aid of a higher branch of industry, and one which gave scope for great artistic achievements - namely, that of painting. ${ }^{129}$

As with Marquardt, a link between creativity and production organisation was assumed, and Birch's opinion was that Roman ceramics were 'produced by slaves and freedmen, whereas at Athens the potter usually held at least the position of a resident alien. These were content to produce useful, but not as a rule fine or beautiful, vases, for the most part only adapted to the necessities of life'. ${ }^{130}$ Birch too put great emphasis on the written word, describing 'the principal shapes of Roman vases, so far as they can be identified from literary or epigraphic evidence', and emphasizing the stamps. ${ }^{131}$

Collection of local archaeological material through small-scale 'excavations' came in vogue as a cheaper, nation-centred alternative to the Grand Tour. ${ }^{132}$ Complete sigillata vessels from graves in the

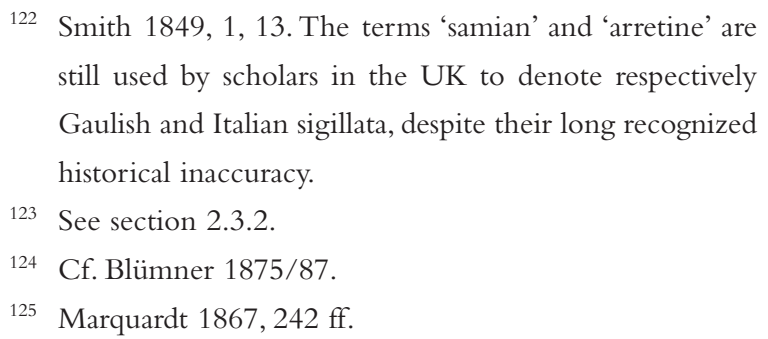

\footnotetext{
126 Marquardt 1867, 254.

127 Marquardt 1867, 254.

128 Birch 1873.

129 Birch 1873, 430.

130 Birch 1873, 434.

131 Birch 1873, 458, 475 ff.

132 Greene 1992, 17.
} 
northern Roman provinces were incorporated in private collections. This led to a number of publications of collections across different - settled or settling - European nations.

For Italian scholars, sigillata's association with classical morality and local pride served the ethos surrounding the unification of Italy (1850s-1870s). ${ }^{133}$ One of the pioneers was Angelo Fabroni, whose Storia degli antichi vasi fittili aretini (1841) focused on the sigillata collection of the Museo pubblico di Arezzo. ${ }^{134}$ Like the general handbooks, Fabroni allocated considerable space to discussion of ancient literary sources, stamps and decoration. ${ }^{135}$ Furthermore, the work repeatedly links aesthetic judgement to economic and political success: aesthetically pleasing pots index a thriving society.

The situation of Germany was akin to that of Italy, in that it was unified rather late, in 1871, and consciously had to craft a nationalist discourse. Antiquities aided this enterprise by creating a shared, national past. Germany too yielded a significant amount of sigillata, originating either from East Gaulish production sites, or from imports to the army forts on the northern frontier (limes). An early study of a production centre and its material was Joseph von Hefner's Die römische Töpferei in Westerndorf (1863). ${ }^{136}$ This work tackled the usual concerns of the time: ancient literary sources, lists of pictorial elements, lists of forms, and accounts of stamps and names. However, von Hefner also included a passing note on chemical analyses ${ }^{137}$, leading him to distinguish two groups, by analogy with the contemporary relation between stoneware and porcelain. Hence a new means of identifying 'real' sigillata was introduced: with the aid of compositional analysis sigillata could be singled out from those pots that looked the same but were not sigillata. ${ }^{138}$ All the while the visual aspect remained pervasive and helped lay the foundations for the German tradition of art-historical study, complemented by excellent drawings. The artist Oskar Hölder for example produced drawings of all forms, figure-types and stamps attested at Rottweil. ${ }^{139}$

In the UK, Charles Roach Smith's On the red glazed pottery of the Romans, found in this country and on the Continent (1849) tried to distance itself from previous antiquarian studies. ${ }^{140}$ Whereas the latter were concerned with sourcing products and identifying pots 'with some special kinds mentioned by ancient authors', Smith set out to fully characterize this class of pottery by means of description and drawings. ${ }^{141}$ A similar tension with the practices of antiquarianism characterizes the preface to Smith's Catalogue of the Museum of London Antiquities Collected by, and Property of, Charles Roach Smith (1854). This served as an apology for his collection of antiquities during construction activities in the city of London and sheds light on the increasing tension between personal acquisitions for aesthetic pleasure and the establishment of museum collections for community education. ${ }^{142}$ Smith eventually sold his collection to the British Museum but had to lower his price because foreign acquisitions were held in higher esteem. ${ }^{143}$

Nevertheless Smith's catalogue continued the aesthetic discourse of antiquarianism, as he praised the 'red-glazed pottery, commonly called Samian', 'distinguished by a superficial beautiful coralline red colour', 'the material on which the greatest taste in design and in ornamentation has been bestowed'. ${ }^{144}$ Recurrent emphasis on stamps and decoration betrays the practice of collecting during casual observation of construction works, retrieving the most salient pieces. ${ }^{145}$ But as with von Hefner, the antiquarian legacy was increasingly pressured by recognition of scientific causal relations. Smith observed for instance that ' $[t]$ he colouring matter is derived from the oxides of lead and iron'. ${ }^{146}$ Finally, while Smith was one

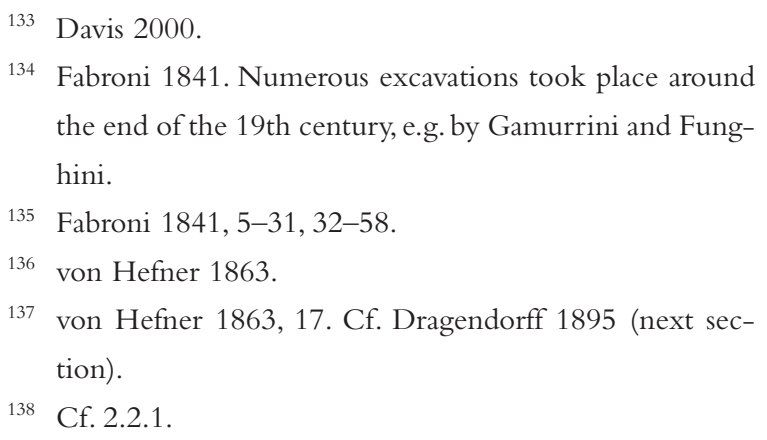

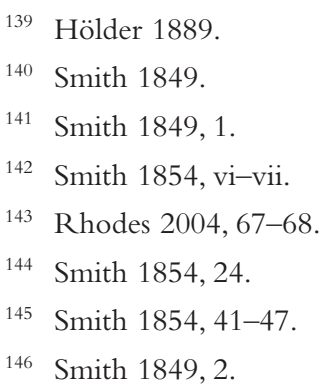


of the first to insist on including drawings of decoration and vessel form, any sigillata specialist today will note how very different his drawings look to the current standard typology. Even directly observed traits such as form and mechanisms such as drawing did not always create sigillata in the same way. As practices and standards changed, so too did sigillata.

In France too, sigillata production centres awakened the interest of antiquarians. Alfred Plicque, a local doctor, claimed to have unearthed 70 workshops and 160 kilns at Lezoux between 1879 and $1894 .{ }^{147}$ The relatively modest structural remains encountered during more recent excavations at Lezoux, however, cast doubt on these numbers. After his death Plicque's collection became dispersed, and the majority ended up in the Musée des Antiquités nationales at St. Germain-en-Laye near Paris. Felix Oswald ${ }^{148}$ acquired a subset of pots from Lezoux and Les Martres-de-Veyre.

To sum up, in the era of antiquarianism sigillata was defined along the axes of the Grand Tour (sigillata as a portable object from a Classical land), emerging nation states (sigillata as an anchor of a distant local past), industrialization (sigillata as a product of creativity and craftsmanship - or not), and the dominance of text (sigillata as carrier of writing). The practices of study relied heavily on visual identification and aesthetics (colour, shininess, form, stamps). Focus was on the study of whole pots within the setting of private collections rather than find contexts.

Despite the emphasis on the complete vessel as index of an individual potter's craftsmanship, increasing awareness of technological characteristics can be noted. Smith mentioned lead and iron oxides as responsible for the red colour, Fabroni discussed clay and slip properties, utensils, and firing procedures in general terms, whereas the second edition of Birch's work referred to chemical analyses undertaken in the course of Dragendorff's work. ${ }^{149}$ This type of excursus, however, never ventured beyond curiosity and did not yet feed into the definition of sigillata.

In this period sigillata was not characterized as a standardized or internally homogeneous product class. On the contrary, scholars highlighted variation in form, decoration and function to signal creativity and virtuosity. While not defined as standardized, sigillata's visual repetitiveness was explicitly distanced from the individual virtuosity of (Greek) painted pottery and (Roman) statuary.

2.3.2 Sigillata AS CORRELATED TRAits (LATE I $9^{\text {Th }}$ - EARLY 2 O $^{\text {Th }}$ CENTURIES)

A series of works published on the verge of the 20th century have come to be regarded as foundational for the study of terra sigillata. Whereas the emphasis was still on the antiquarian criteria of form, decoration, and whole vessels rather than fragmentary potsherds, sigillata studies moved away from aesthetic judgement. Rather than discussing the different attributes of sigillata separately, scholars understood that a meaningful correlation might exist between decoration, form, and stamps. This shift can be linked to the rise of prehistoric and culture-historical archaeology, brought to fruition later by scholars such as V. Gordon Childe who turned to assemblages as a means of defining a cultural group. ${ }^{150}$ On the other hand the concern for typology and classification which loomed large in this time frame was inspired by an evolutionary paradigm, tracing the development of forms through time based on minor stylistic variations. When placing the following works in their respective contexts, it is important to keep in mind the limited state of fieldwork at the time.

Hans Dragendorff, for example, based his seminal sigillata typology (1895) solely on recorded specimens from cemeteries - often associated with coins - and on a number of historically dated sites. It is unclear whether his numbering of drawings was meant to be read as the formal 'typology' it was later taken to be. On the one hand, Dragendorff was clearly heir to the preceding art-historical tradition.

147 Plicque 1887.

148 See section 2.3.3.
149 See section 2.3.2.

150 Childe 1929; Trigger 1980. 
For example, a posthumous publication focused solely on decorated Italian sigillata, listing characteristic figure-types for each identified workshop. ${ }^{151}$ On the other hand, evolutionary thought now replaced the previous moral association of aesthetic judgment. As such, the observation that Roman sigillata was produced in 'Fabriken, die einen an moderne Verhältnisse erinnernden Massenexport entwickeln', no longer carried a negative connotation, on the contrary. But sigillata scholarship never indulged in the same civilizing discourse as did the contemporary vigorous writings on Romanization. ${ }^{152}$ Pottery had to cede place to cities, buildings, and inscriptions as an empirical basis for Romanization studies, and ceramologists did not venture far into the lands of social and cultural analysis. Importantly, the entire Romanization debate has always been a UK-based phenomenon - partly because of its origin in Victorian ideology - whereas the study of sigillata engaged scholars all over Europe and the UK, taught in very distinct national traditions.

But despite continuing an art-historical thread, Dragendorff also innovated sigillata studies. First, his ambition was to operate on a larger geographical scale, in contrast to earlier studies limited to single findspots. ${ }^{153}$ Secondly, a more holistic approach replaced the separate headings of 'form', 'decoration', 'stamps' etc. of the antiquarian phase, as Dragendorff had witnessed the birth of the culture-historical paradigm in Germany. ${ }^{154}$ Thirdly, some sense of technology can be discerned - albeit in the guise of curiosity: chemical analyses of five sherds were requested from a pharmaceutical institute. ${ }^{155}$ This led to a technological reading of the shiny red colour, as caused by iron oxide and as indicating a specific clay selection rather than clay treatment. Iron oxide became a new defining aspect of sigillata, and potters were transformed from creative virtuosos (or their mirror image of passive, capitalist slaves) into knowledgeable technicians.

In France Joseph Déchelette published Les vases céramiques ornés de la Gaule romaine (1904), a study of decorated ceramics, including sigillata, from three provinces of Gallia. The definition of his subject on the basis of the presence of decoration followed a traditional line of inquiry. But the geographical scope of his work speaks to Dragendorff's urge for expansive surveys of ceramic material. Déchelette's study also heralded some of the innovations of the next phase. At the outset, he listed two main research questions: firstly, identification of production centres based on decorative schemes, and secondly, the chronology of vessels. ${ }^{156} \mathrm{He}$ also took up the evolutionary concept of fossils directeurs, with evolution measured on the basis of decoration, not vessel form. ${ }^{157}$ Variability was understood temporally instead of spatially or socially. In his definition of sigillata as 'les vases à vernis rouge et les vases d'une couverte autre que le rouge, mais ressemblant aux précédants, soit par leurs formes, soit par leur technique ${ }^{158}$, the criteria of colour, stamps, and decoration had given way to an emphasis on form and technology. Moreover, Déchelette added a number of forms to Dragendorff's typology.

Meanwhile the foundations were laid for the rigorous cataloguing of stamps, one of the threads running through the entire history of sigillata scholarship. Ihm and Dressel each took charge of producing a volume of the Corpus Inscriptionum Latinarum listing stamps on Italian sigillata. ${ }^{159}$

These foundational works heralded new ways of studying and defining sigillata. In Germany the dawn of culture-historical archaeology fed into the conceptualization of sigillata as an assemblage of individual traits that could be correlated with one another. Familiarity with affiliated disciplines such as geology led to the presumption that some traits were not immediately visible to the eye. The shiny red colour for example became the articulation of iron oxide instead of an index of the potter's creativity. Moreover, the specific rendering of these traits could vary between different pots: Déchelette for example expanded

151 Dragendorff/Watzinger 1948.

152 Haverfield 1905. See Hingley 2000; Van Oyen 2015a; Vasunia 2005 for the relation between Roman studies and the political context of the British Empire.

153 Dragendorff 1895, 22.

154 Before Childe took it on board in the UK (Trigger 2006,
235).

155 Dragendorff 1895, 19-20.

156 Déchelette 1904, III.

157 Déchelette 1904, III.

158 Déchelette 1904, 19.

159 Menchelli 2005. 
the criterion of 'colour' beyond red. Also, some traits such as form or decoration were acknowledged to have varied through time.

Building on and reinforcing these parameters were the new practices of studying sigillata. General classifications became an appropriate tool for processing this newly defined sigillata. Sigillata had become a mass-produced class with similarities across production sites, and hence specimens from as many origins as possible needed to be classified together. Each form was identified first through a drawing, and later on with the corresponding number from the Dragendorff series. Later on these steps were filtered out, and nowadays the number is seen to logically refer to a prior reality of a certain well-defined form - a prime example of how a retrospective approach works. The praise for creativity was tempered, and technology came to be considered as the human mastery of nature, developed in a unilinear progression. ${ }^{160}$ Moreover, the relation between sigillata and other finds such as coins was now defined by co-occurrence in find contexts instead of co-occurrence in collections.

\subsubsection{Sigillata A A Dating TOOL ( 2 O $^{\text {Th }}$ CENTURY)}

The evolutionary principles introduced in the previous phase came to dominate Roman pottery studies in the early and mid 20th century and put chronology and dating centre stage. The World Wars had revealed a globally connected scene, an ethos that was reinforced by the evolutionary and Marxist principle that all societies went through a similar sequence of development. A series of site reports on historically dated sites enabled the integration of rigorous typological schemes in fairly precise chronological sequences. Especially the army forts along the limes in between Rhine and Lippe (e.g. Haltern, Oberaden) provided tight chronological control of typologies given their historically attested short-lived occupations. The excavations of these forts greatly expanded the empirical basis of sigillata studies, which for the first time turned to assemblages of broken potsherds instead of whole vessels. Much effort went into correlating different details of decorative schemes and figure-types, rim and base variations, and stamps, so as to arrive at a broader range of criteria for comparative dating. Curle, Walters, Ludowici, Loeschcke and Ritterling made additions to Dragendorff's typological scheme. Whereas evolutionary principles distanced the past - and sigillata - and rendered it more 'objective', the subservient nature of sigillata scholarship to history lingered on in a twofold way: firstly, historical sources anchored typological chronologies; and secondly, the conceptualisation of sigillata sherds as a dating tool merely responded to the needs of ancient history.

In 1909 Georg Loeschcke - Dragendorff's teacher - presented a study of all ceramic types found in the Roman fort at Haltern. He acknowledged the promise for establishing an absolute chronology given the short depositional range of the ceramics at Haltern, 'höchstens 20 bis 25 Jahre'. ${ }^{161}$ Within an historical framework set by literary sources (on Varus and Germanicus) and stamps ${ }^{162}$, Loeschcke devised a new sigillata typology of four 'services' with distinctive rim morphology ${ }^{163}$ His work was further innovative by considering the entire ceramic assemblage from the site, including the wares other than sigillata, and by reference to the actual excavation.

Emile Ritterling, in turn, undertook excavations at the Roman fort at Hofheim between 1902 and 1903, and published the results in 1913. Here too, ancient sources set the research questions. Ritterling was particularly interested in the foundation date and duration of the fort in order to prove: 'das in dem Hofheimer Lager eine Befestigung angusteischer Zeit, sogar das vielgesuchte von Drusus angelegte „praesidium in

160 Pfaffenberger 1992.

161 Loeschcke 1909, 119.

162 Loeschcke 1909, 121-123, $167 \mathrm{ff}$.

163 Loeschcke 1909, 136. Most sigillata at Haltern was of
Italian origin, and was later discussed in relation to the location of Ateius' workshops: Bruni 1995; Picon/ Garmier 1974; Desbat 2004; Desbat/Genin/Lasfargues 1996. 
monte Tauno "gefunden sei". ${ }^{164}$ The majority of the work presented the archaeological finds in view of their potential as dating fossils, which led to a focus on the chronology of types and stamps for sigillata. ${ }^{165}$

In 1914, Atkinson published 90 decorated sigillata vessels contained in a wooden box that was burnt during the historically attested destruction of Pompeii in AD 79. Atkinson's account introduced a series of tools for dating sigillata assemblages: the ratio of forms Drag. 29 and Drag. 37, the decorative details by potter, the quality of the execution ('carelessness in technique', not as much as a judgment of value or identity, but as a chronological index), and elaborate drawings enabling comparison. ${ }^{166}$

This use of historically dated sites was soon put into practice, for example by Ludowici who excavated at the East Gaulish production centre of Rheinzabern between 1901 and 1914. Ludowici epitomizes the transformation of sigillata and its scholarship: he started off as an industrialist enchanted by the "schönen, roten Terra sigillata-Glasur ${ }^{167}$, but gradually incorporated the prevailing chronological concern in his work, to arrive at a chronological sequence of the Rheinzabern potters. Meanwhile he devised a detailed scheme for referencing decorative figure-types, with general thematic categories (e.g. $M=$ humans and gods) subdivided into numbered variations, linked to different potters' repertoires. ${ }^{168}$

Another example of the application of chronologically anchored typologies is J.P. Bushe-Fox' use of sigillata in dating the early Roman occupation of northern Britain. He too relied on the ratio of forms Drag. 29 and 37 and the type and execution of decorative details. ${ }^{169}$ Sigillata studies' role was that of dating historical events:

'Early historians tell nothing of the sites occupied by the Romans in their first campaigns against the northern tribes. No inscription of this period has been found in the north, and in most cases the coins are few and, by themselves, do not form sufficient evidence from which to draw definite conclusions. Great advances have been made, however, of late years in the dating of pottery; most of the northern sites that have been excavated have produced a fair amount of Terra Sigillata or Samian ware, and with the evidence afforded by this it has been possible to assign several sites to the time of Agricola, and others to a period that is certainly pre-Hadrianic. ${ }^{170}$

This led to a circular argument in which pots dated by means of historical evidence were then used to fill in the blanks in this historical evidence (in particular Tacitus' Agricola). The uptake of sigillata's dating potential in general archaeological practice is remarked on by Haverfield: 'Potsherds, when we can date them, and we are slowly learning how to do this, are as valuable chronological material as even coins'. ${ }^{171}$ The same passage, however, has Haverfield lamenting 'the brutal monochrome of Roman pottery gives us no such chronological clues as the varied colouring of modern porcelain.' This illustrates how old specialist judgements lingered on in popular imagination.

Meanwhile general handbooks summarized these tools, especially Oswald and Pryce's An Introduction to the study of Terra Sigillata (1920). Tellingly, the subtitle read Treated from a Chronological Standpoint, and in the preface too, special focus was ascribed to the chronological importance of forms and styles. ${ }^{172}$ The seventh chapter for example was entitled 'Details of chronological significance', discussing the frequency and style of decorative details in relation to forms, production centres, and, of course, date. ${ }^{173}$ The overarching evolutionary rationale showed in a preoccupation with tracing origins of forms and decoration.

In Germany, Robert Knorr acknowledged the dating potential of sigillata sherds: 'Bei Geschichtsforschungen über Kultur, Handel, Verkehr und grosse Ereignisse des ersten Jahrhunderts haben sich kleine Sigillatascherben als zuverlässige und unzweidentige Zeitmarken der absoluten Chronologie erwiesen; ähnlich wie die Leitmuscheln und

\footnotetext{
164 Ritterling 1913, 2-3.

165 Ritterling 1913, 67-76.

166 Atkinson 1914, 29-32.

167 Ricken/Thomas 2005, 4-5.

168 Ricken/Fischer 1963.
}

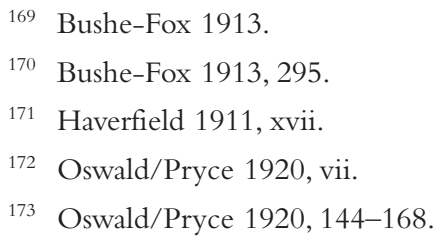


Fossilien der Geologen und Paläontologen die relative Chronologie geologischer Schichten klären.' ${ }^{174} \mathrm{He}$ was in particular concerned with producing accurate drawings for reference purposes, and believed that 'Sigillatagefässe muss man selbst sprechen lassen durch geordnet vorgelegte Abbildungen'. ${ }^{175}$ Here sigillata is seen to speak for itself: if represented in the right way, one could 'read' its chronological sequence. All the while, within the German art-historical tradition sigillata remained the pinnacle of 'gallo-römischen Kunsthandwerks' ${ }^{176}$.

Triggered by his acquisition of the Plicque collection ${ }^{177}$, Oswald published two sequels to his general handbook, in which he made a case for the chronological potential of stamps and figure-types respectively. ${ }^{178}$ The German scholar August Oxé's stamp catalogue was posthumously reworked and published by Howard Comfort as the Corpus Vasorum Arretinorum. ${ }^{179}$ Again, the emphasis was firmly on dating: 'Denn gerade die Funde am Rhein und an der Lippe haben bisher die zuverlässigsten Stützen geliefert für die absolute Datierung der arretinischen Keramik (...) ${ }^{180}{ }^{180}$ Like his colleague Knorr, Oxé's work betrays a German art-historical tradition, with casual remarks on the links of sigillata decoration to 'der grossen griechischen Kunst'. ${ }^{181}$

It might be too far fetched to bring in the post-World Wars ethos to account for new ways of defining sigillata. And yet the general climate of the time was one of acute chronological awareness, which proved compatible with the principles of evolution encountered in the previous phase. Combined with a continuing emphasis on written sources, the chronological concern helped write a homogeneous Roman history for Western Europe. Sigillata was transformed once again, from a value-laden symbol to an 'objective' tool for framing this global history by dating historical events. Scholars in the previous phase had set the stage for these developments by assembling sigillata pots from different sites and regions, and thus implicitly equating them analytically. Woven into the new historical texture was a different articulation of typologies. At a very basic level this is apparent in the process by which the random numbers of Dragendorff's drawings now ended up as a rigid typology with global validity. 'Types' became chronological fossils, and sigillata a method rather than a goal for study.

The 'sigillata dating method' was fairly straightforward. As Knorr phrased it, 'sigillata speaks for itself', provided it was represented in an objective and detailed way. Sigillata was now articulated through assemblages of potsherds, grouped by find context, and became part of the history of this find context rather than of a technological pottery spectrum. Arranging and rearranging these sherds and their attributes for example through charting form ratios - eventually allowed sigillata to 'speak for itself'. Sigillata had thus become a neutral carrier of a historically dated event, a homogeneous package of traits that could be studied by trait - for instance, comparing the similarity and difference of one figure-type to another.

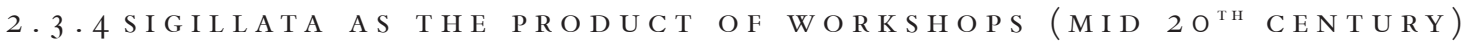

A landmark in the history of sigillata studies was Stanfield and Simpson's Central Gaulish Potters (1958). The title heralded a new focus on the identification of individual potters, beyond a concern with dating. Stanfield dedicated his spare time from his job at the Admiralty to the study of sigillata in London museums, and cultivated archaeological friendships with influential figures such as Mortimer Wheeler. Eventually, Grace Simpson was recruited to complete Stanfield's work and became one of the prominent figures on the sigillata stage herself. ${ }^{182}$

174 Knorr 1952, viii, 1919.

175 Knorr 1952, ix.

176 Knorr 1952, x.

177 See section 2.3.1.

178 Oswald 1931, 1936/7.

179 Oxé and Comfort 1968. The work - limited to Italian sigillata - built upon previous studies by Oxé (1933, 1934; Stieren 1943) of ceramics found in Haltern and the
Rhine area.

180 Oxé 19331.

181 Oxé 1933, 2.

182 Grace Simposon was the daughter of F. Gerald Simpson, excavator of Hadrian's Wall. She later reworked antiquarian notes by Rossignol on decorated Montans sigillata (Simpson 1976). 
Central Gaulish Potters reached back to the earliest phases of sigillata scholarship in two ways. First, the actual material under study consisted of part of the Plicque collection, acquired by Oswald, and then transferred to Durham by Eric Birley. ${ }^{183}$ Secondly, the work claimed to follow in the tracks of Déchelette and Knorr: 'study of the Central Gaulish potters should in principle be modelled on Knorr's treatment of their first-century South Gaulish predecessors', and 'Stanfield made Les vases céramiques ornés de la Gaule romaine by Joseph Déchelette his constant working partner. ${ }^{184}$

The prime focus in this phase was on decoration. In line with Knorr's standards, drawings were made with great care. Stanfield was renowned for his accurate drawings, and later others such as Rogers were tasked with providing drawings for publication. The method of study of the decoration, however, was quite different from that of Knorr's time. Hofmann devised a new scheme for the study of decorated bowls, beginning with the producers of figure stamps (poinçons), and setting identification of the masterstylist or mould-maker as the distant goal. ${ }^{185}$ Figure-types alone were no longer seen as conclusive in the attribution of sherds to individual potters, contrary to Déchelette's approach. Overall style and details less likely to be shared among potters - especially the ovolo or beaded rim decoration - became the decisive elements for identification. This resulted in the (re)construction of fictive identities such as 'the potter with the cross detail' or 'the untidy potter'. ${ }^{186}$

Detailed studies of different potters' styles led to an awareness of the links between potters through copying, use of similar figure-types, repetition of overall organisational schemes, etc. This type of enquiry opened a new area of study, concerned with issues of production organisation - a topic further pursued in recent works. Statistical analysis aided comparison of ovolo's, stamps and decorative elements. ${ }^{187}$ With regard to Italian sigillata this trend took off later, with Pucci first showing interest in economic and social aspects of production. ${ }^{188}$

Although chronology receded to the background, it was not forgotten. In line with the focus on individual potters and their production relations, emphasis was on dating the working lives of these potters, and, as a consequence, of their output. ${ }^{189}$ But Stanfield and Simpson attempted to cut loose from the preceding chronological endeavours by establishing ' $[\mathrm{a}] \mathrm{n}$ entire new chronology (...), based solely on North British site evidence, in order to avoid bias from published works (...). ${ }^{190}$ Nevertheless, in the actual corpus of the book, the dating of each potter is reduced to a brief note at the end of each section. Rogers in turn used the physical association of a pile of wasters to establish the contemporaneity of the styles represented in order to refine the chronology of Stanfield and Simpson. ${ }^{191}$

As to the format of the publications, it is significant that Central Gaulish Potters remained the only substantial monograph - much in contrast to previous phases. The switch to journal articles opened up scope for diversification of interests. Simpson, for example, not only wrote about decorated sigillata, but also devoted some time to the study of black-slipped sigillata, to sigillata production in Britain, to other small finds and metalwork, and to revising the chronology of Roman Wales. Rather than authoring major studies, sigillata scholars increasingly focused on specialist contributions to site reports.

Scholarship on Italian sigillata was revived by Arturo Stenico and by Christian Goudineau's study of the plain sigillata from French excavations at Bolsena. These studies too explicitly aligned with founda-

183 Birley's part of the Plicque assemblage was later sold to the University of Durham. Another part of the collection - not acquired by Birley - moved to Nottingham University via Oswald.

184 Stanfield/Simpson 1958, xvii, xxxi. Little reference was made to the preceding 'chronology' phase.

185 Hofmann 1971.

186 Note the parallel to Beazley's contemporaneous attempts at linking stylistic details of Greek painted vases to indi- vidual painters/potters, e.g. 'the Berlin Potter'. These potters were actually creations of connoisseurship (Melius 2011).

187 See Simpson/Rogers 1969.

188 Pucci 1985; Menchelli 2005.

189 See Simpson 1957, 35 and 1976, 269; Simpson/Rogers 1969,5

190 Stanfield/Simpson 1958, xliii.

191 Rogers 1977. 
tional works, especially by Dragendorff and Watzinger. ${ }^{192}$ Furthermore, much like Stanfield and Simpson, Stenico urged the specialist studying decorated sigillata to exhibit 'una generica riserva sulla validità del procedimento attribuzioni'. ${ }^{193}$ Finally, an interest in individual potters is indicated by Stenico's analysis of the output of Rasinius, engaging with questions of production organisation. ${ }^{194}$ Typology and chronology featured as stepping-stones towards broader debates.

Bypassing its previous definition as a dating tool, in this phase sigillata also became the result of a specific mode of production organisation, that of the creation and circulation of styles and decorative details. Sigillata was not as much a pot or a set of potsherds but a style, the recorded attestations of a specific ovolo or other details, situated at the interstices of relations between mould-makers, producers of figure stamps, and potters.

The practices of study did not change radically, in that the credo of the 'accurate representation' was still in place. What did change was the nature of the sample in which sigillata was placed, which shifted from an emphasis on find context to the output of a (set of) production centre(s) and their workshops. If sigillata was still thought to speak for itself, its 'grammar' became more specific - for example through decorative details - and, so was thought, more scientific. The use of statistical analysis aligned with this strive for objectivity.

\section{3 .5 Sigillata HAS NOT ALWAYS BEEN The SAME Thing!}

After the 1970s, we can refer back to the 'survival guide' with which this chapter started, as it covers the most recent definition of terra sigillata. One way of reading the previous pages would be as different ways of interpreting an external, stable, unchanging essence of sigillata; as a story of tools and methods for studying sigillata that were gradually refined throughout the different phases, allowing us to access more and more of what sigillata really is. This is the retrospective approach, starting from the conclusion. One of the downsides of such an approach is that the connections between the different phases are ignored: the phases link up merely because they all talk about the same thing, terra sigillata.

But if, as in the above descriptions, the practices of study in the different phases are taken seriously, it becomes clear that sigillata was defined rather differently throughout its history of scholarship: from a second-rate collector's item defined on the basis of aesthetic judgement, over an assemblage of traits that could be ordered chronologically, to a product of individual potters with specific styles. These differences had consequences for how sigillata's historical role was imagined. Focus on its aesthetic repetitiveness placed sigillata in a pre-modern capitalist world ${ }^{195}$, whereas analysis of decorative details traced a closelyknit community of craftsmen ${ }^{196}$. In the first phase, sigillata was indicative of a nation's specificity, only to become a shared (European) thing later on.

Starting from the differences between the phases forces us to think harder about what makes all of them hang together as a history of 'sigillata' scholarship. Reflecting on these connections helps clarifying some oddities that have no place within a retrospective approach. For example, despite their jettisoning since the time of C.R. Smith, the terms 'samian' and 'arretine' are still used by scholars in the UK to denote respectively Gaulish and Italian sigillata. This serves as a warning that the history of sigillata scholarship is more than a story of increasing accuracy. Practices cannot be eradicated instantly, but have a certain path-dependency and shape the possibilities for study in the next phases. The current scholarly construction of sigillata as a homogeneous category is not an inevitability, but the outcome of a contin-

192 Dragendorff 1895; Dragendorff/Watzinger 1948. References in Goudineau 1968 and Stenico 1960,10.

193 Stenico 1966, 11.

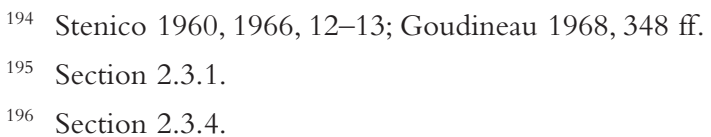

194 Stenico 1960, 1966, 12-13; Goudineau 1968, 348 ff.

196 Section 2.3.4. 
gent historical trajectory. For instance, it is only because Dragendorff and others started insisting on the compilation of region-wide studies that sigillata became seen as 'the same everywhere' - homogeneous and widely spread. Once this step was taken, sigillata became a potential chronological anchor. Its use as a chronological tool for writing history in turn prepared the economic and cultural narratives discussed in the introduction, in which sigillata features as 'the same everywhere' and can be used to chart economic and cultural (rather than, or in addition to chronological) patterns.

\subsection{W H I T HER S I G I L L A T A ?}

Before continuing it is crucial to be transparent about this book's aspirations for sigillata scholarship. It is not the aim to get rid of the term terra sigillata, or to say that there can be no definable or productive class of sigillata. Denying an a priori essence to this category is a strategy to pull out more of the differences that have previously been erased (the category's 'bleeding'), and to challenge scholars to make sense of these differences. To clarify this with a random example: as I am writing this, I am sitting on a chair in the library, as are many others around me. We all sit on our chairs in a slightly different way (this would be the changing meaning suggested by biographical approaches, or the different phases of study in a retrospective history of sigillata scholarship), but no one would doubt the 'chair-ness' of the chair, or its difference from other things in the library such as tables or shelves, which are not used to sit on even though this would technically be possible. In this setting, a chair is defined as 'what one sits on when working in a library'. But imagine a sudden fire in the library. In the instant panic the sturdy library chairs will lend themselves to breaking the windows and opening up an escape route. But so will the tables and the shelves: the difference between them is blurred in this setting, and the 'chair-ness' of the chair is no longer evident and relevant. Instead, in the changed setting the chair becomes part of a larger category defined as 'what one can use to escape from a fire in the library'. Acknowledging how these similarities and differences change from one setting to the next ('in-the-doing', in everyday practices) is what this research is about. ${ }^{197}$

The goal is to come to understand the historical processes that led sigillata to be defined as a homogeneous, widespread category, in past and present. Deconstruction of the category of sigillata - no longer taking it for granted - is thus an essential prerequisite to putting due emphasis on its historical construction! My account of sigillata scholarship is therefore not a negative one; on the contrary, I believe that rather more could be got out of it. My stance is a pragmatic one. Even if sigillata as a homogeneous category is a modern construct, it is in some ways well-constructed and does a lot of useful work in channelling knowledge. It allows archaeologists to date sites to within a couple of decades, it creates a disciplinary coherence, and it spurs economic and cultural reconstructions of the Roman world. But pointing out just how it is being constructed, as this chapter did, is necessary to allow sigillata pots to play a more active role in our historical narratives, instead of functioning as neutral props on distribution maps. Again, the credo is that 'more is in sigillata'.

On the one hand, then, sigillata was being constructed and redefined as it moved in and out of different settings and practices. On the other hand, its 'construction' was very physical too: sigillata pots were being produced, distributed, and used, often in widely distant localities. Now that this chapter has introduced the shift in perspective through study of present practices surrounding sigillata, it is time to move onto its past practices. The following chapters will trace how sigillata pots were (re)defined along their trajectories of production, distribution, and consumption in the Roman world.

197 Theoretically, it follows the lead of Science and Technology Studies, as in Latour 1999, 2005; Law 2002; Law/
Mol 2008; Mol 2002; Pickering 1984. See Van Oyen

2015b for more theoretical implications. 
